B. Bourouis, H. Djeghloud, H. Benalla

\title{
ENERGY EFFICIENCY OF A 3-LEVEL SHUNT ACTIVE POWER FILTER POWERED BY A FUEL-CELL / BATTERY DC BUS WITH REGULATED DUTY CYCLES
}

\begin{abstract}
Introduction. Nowadays, electrical energy is indispensable in industrial, tertiary and domestic appliances. However, its efficiency is becoming affected by the presence of the disturbances that appear in the electrical networks such as harmonics, unbalance, sags/swells, flickers ...etc. Indeed, the disturbances cause a decrease in the power factor and an increase in the power losses. In this paper, the harmonic disturbance is considered and a 3-level shunt active power filter powered by a hybrid fuel-cell/battery DC is applied to mitigate current harmonic components from the electrical feeder. Aim. Studying the energy efficiency of a system based on a 3-level shunt active filter powered by a hybrid fuel-cell / battery DC bus. Methodology. It is a matter of finding the suitable formulas that express the efficiency and the relative power losses according to the load factor (which is the ratio between the shortcircuit active power and the load active power) and the load power factor. The DC bus energy is controlled using an energy management algorithm that contributes in generating the required reference input currents and output voltages of the fuel-cell and the battery. The DC/DC converters control circuits are performed in a closed loop by means of regulated duty cycles. Results. The simulation results carried-out under MATLAB/Simulink environment show better filtering quality if compared with the case of open loop control of the DC/DC converters and lesser differences between the fuel-cell power, the battery power and their respective reference powers. Which concerns the energy efficiency, the results demonstrate that higher efficiency and lower relative power losses can be achieved only when higher load factor and load power factor are attained. Therefore, the compensating system of the power factor is very important to improve the energy efficiency. References 13, tables 1, figures 14.
\end{abstract}

Key words: 3-level shunt active power filter, hybrid fuel-cell / battery DC bus, energy efficiency, power quality, efficiency, relative power losses.

Bступ. У наш час електрична енергія є незамінною для промислових, проміжних і побутових приладів. Однак на ї̈ ефективність впливає наявність порушень, що виникають в електричних мережах, таких як гармоніки, дисбаланс, провисання/розбухання, мерехтіння тощь. Дійсно, порушення викликають зменшення коефіиієнта потужності та збільшення втрат потужності. У иій роботі розглянуто гармонічні порушення та застосовано 3-рівневий шунтуючий фільтр активноі потужності з живленням від гібридного паливного елемента/акумулятора постійного струму для пом'якщення струмових гармонічних компонентів з електропостачанням від електричного фідера. Мета. Дослідження енергоефективності системи на основі 3-рівневого шунтуючого активного фільтра з живленням від гібридної шини постійного струму з паливним елементом/акумулятором. Методика. Потрібно знайти відповідні формули, які виражають ефективність та відносні втрати потужності у відповідності до коефіцієнта навантаження (ие відношення активної потужності короткого замикання та активної потужності навантаження) та коефіиієнта потужності навантаження. Енергія иини постійного струму контролюється за допомогою алгоритму управління енергією, який сприяє формуванню необхідних опорних вхідних струмів та вихідних напруг паливного елемента й акумулятора. Схеми управління DC/DC перетворювачами виконуються у замкненому контурі за допомогою регульованих робочих ичилів. Результати. Результати моделювання, проведеного у середовищі MATLAB/Simulink, показують краму якість фільтрачії у порівнянні з випадком управління з відкритим контуром DC/DC перетворювачів та менші відмінності між потужністю паливних елементів, потужністю акумулятора та їх відповідною порівняльною потужністю. Що стосується енергоефективності, результати показують, що більший ККД та менші відносні втрати потужності можна досягти лише тоді, коли досягаються більший коефіиієнт навантаження та коефіцієнт потужності навантаження. Тому компенсуюча система коефіцієнта потужності дуже важлива для підвищення енергоефективності. Бібл. 13, табл. 1, рис. 14.

Ключові слова: 3-рівневий шунтуючий фільтр активної потужності, гібридна шина постійного струму 3 паливним елементом/акумулятором, енергоефективність, якість електроенергії, ККД, відносні втрати потужності.

1. Introduction. The study of the electrical systems energy efficiency is very important since electricity is the most flexible type of energy and one of the most significant energies used in industry and in domestic appliances. Particularly, for systems containing power quality compensators based on power electronics interfaces, it is interesting to study the influence on the global system efficiency. Indeed, when the power quality is poor, power losses increase which decreases the efficiency [1-3]. Active power filters (APFs) are classified among the most effective power quality compensators that can reduce the power losses according to the adopted compensation approach and consequently improve the energy efficiency [4,5]. Particularly, the shunt active power filter (SAPF) generates a current which reactive component goes into the non-linear load whereas the active component flows into the source while guarantying less power losses and near-unity power factor (in spite of the energy losses in the APF electronic devices) $[6,7]$. The study of the energy efficiency of a compensated power system can be performed depending on the power system topology, the existent disturbances that increase the power losses and the compensation approach. In the literature most studies concern the energy efficiency of four-wire power systems taking into account the neutral current in presence of harmonic disturbance and considering the instantaneous power theory in the compensation approach $[4,6-8]$. Especially, the study presented by Artemenko and Batrak in [6] establishes new formulas that call the load factor (ratio between the shortcircuit power and the load active power) and the load power factor when expressing the system global efficiency and relative power losses. The study demonstrates that more the load factor and the power factor are higher, the efficiency is higher and the relative 
power losses are lower which means better energy efficiency.

In the present work, the formulas of Artemenko and Batrak are adopted on a three-phase three-wire system considering a 3-level neutral point clamped (NPC) SAPF powered by a hybrid fuel-cell (FC) / battery DC bus which power is supervised by a management energy algorithm associated to DC/DC boost and buck converters where the duty cycles are closed-loop controlled.

The purpose of the work is studying the energy efficiency of a system based on a 3-level shunt active filter powered by a hybrid fuel-cell / battery DC bus.

The present work is organized as follows. Section 2 describes the global system. Section 3 is dedicated to the SAPF and the DC bus topologies and control strategies. Section 4 establishes the theoretical study of the energy efficiency according to Artemenko and Batrak approach.
Section 5 presents and discusses the simulation results carried-out using MATLAB/Simulink.

2. Active filtering system description. The considered system is depicted in Fig. 1. The system contains the electric feeder (with its electromotive force (EMF) $e_{s}$, its series $R_{s}, L_{s}$ impedance, and its current $i_{s}$ ) to be cleaned from harmonic currents (produced by the load), the non-linear load (a diode rectifier and a DC $R_{l}$, $L_{l}$ load) and the proposed 3-level NPC IGBT's active power filter configuration (with its output filter $R_{f}, L_{f}, C_{f}$ and its upstream filter $R_{u}, L_{u}$ ) which DC bus (including the filtering capacity $C_{d c}$ with its shunt resistor $R_{d c}$ ) is fed with a DC voltage $V_{d c}$ through a hybrid system of a FC and a battery, power electronically interfaced by DC/DC boost and buck converters. The detailed description of this hybrid power DC bus and the energy management system are presented in [9]. Duty cycles controllers of DC/DC converters and energy efficiency of the AC side are shown in the following sections.

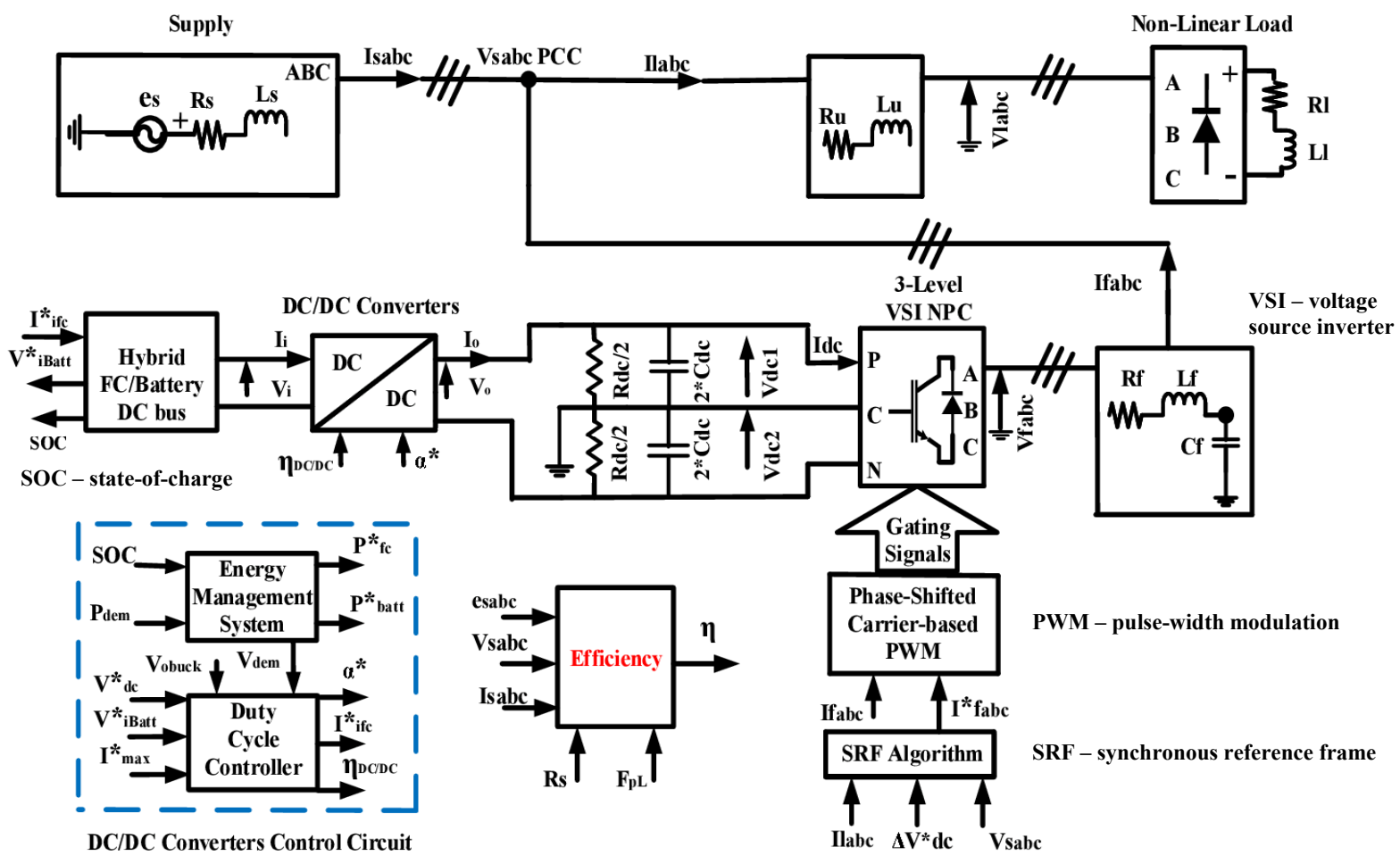

Fig. 1. Description of system

3. SAPF and DC/DC converters topologies and control strategies. As said previously, the SAPF is based on a NPC 3-level voltage inverter and the DC bus feeding the SAPF with DC voltage. The DC bus is based on an association of a FC, a battery and DC/DC boost and buck converters. Topologies and control strategies of the SAPF and the DC/DC converters are presented in this section.

3.1. SAPF. Figure 2 illustrates the power circuit of the SAPF constituted of a DC voltage bus, a NPC 3-level voltage inverter and an output RLC filter. The control strategy of the SAPF is shows in Fig. 3. It uses the synchronous reference frame (SRF) to detect the reference harmonic current $I_{f}^{*}$, PI correctors to regulate the input DC voltage $V_{d c}$ and the output AC current $I_{f}$, and a phase-shifted carrier-based modulator for gating signals generation. The PI correctors coefficients of the voltage regulator $\left(K_{p V d c}, K_{i V d c}\right)$ and the current regulator $\left(K_{p I f}, K_{i I f}\right)$ are designed using Bode method. Their expressions are extracted by the help of (1) to (8) [10] starting from the open loop transfer functions (OLTF) of the DC voltage $\operatorname{OLTF}_{V d c}(p)$ and the $\mathrm{AC}$ current $\operatorname{OLTF}_{I J}(p)$.

\section{2. $V_{d c}$ regulator}

$$
O \operatorname{LTF}_{V_{d c}}(p)=\left(1+\frac{K_{p V_{d c}}}{K_{i V_{d c}}} s\right) / \frac{a}{K_{i V_{d c}}} s^{2} ;
$$

where

$$
\begin{gathered}
a=\frac{C_{d c} \cdot V_{d c}^{*}}{3 V_{s r m s}} ; \\
K_{p V_{d c}}=\frac{K_{i V_{d c}}}{\omega_{1}}, \quad K_{i V_{d c}}=a \cdot \omega_{0}^{2}
\end{gathered}
$$




$$
\begin{aligned}
& \omega_{1}=\frac{\omega_{c}}{\tan \left(\phi_{1}\left(\omega_{c}\right)+\pi\right)} \\
& \omega_{0}=\frac{\omega_{c}}{e^{0.25 \cdot \log (10) \cdot \log _{10}\left(1+\left(\frac{\omega_{c}}{\omega_{1}}\right)^{2}\right)}},
\end{aligned}
$$

where $\omega_{c}$ is the cutting frequency in the DC state generally chosen inferior to the fundamental frequency; $\phi_{1}\left(\omega_{c}\right)$ is the angle belonging to the phase margin, and $\omega_{0}$, $\omega_{1}$ are the particular frequencies of the Bode diagram.

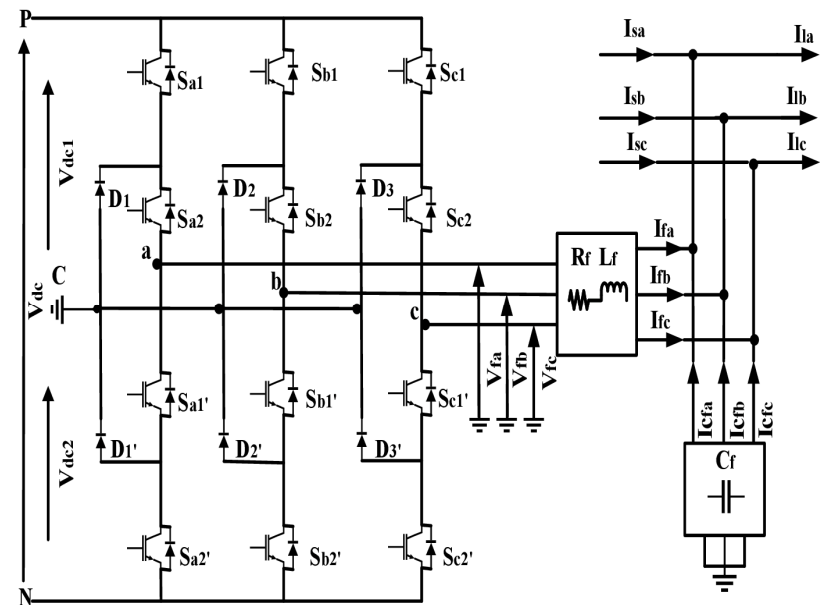

Fig. 2. SAPF topology

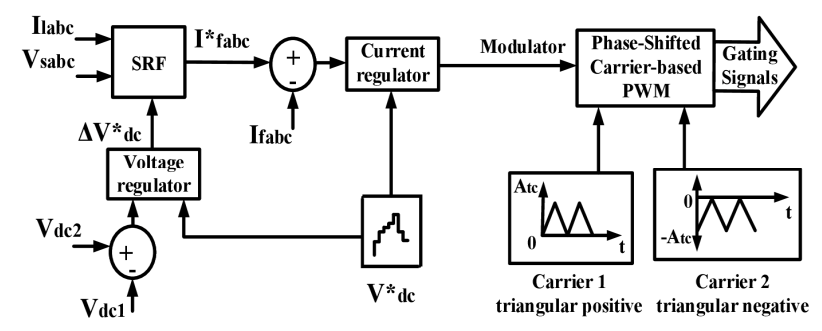

Fig. 3. SAPF control strategy

\section{3. $I_{f}$ regulator}

$$
\operatorname{OLTF}_{I_{f}}(p)=\left(1+\frac{K_{p I_{f}}}{K_{i I_{f}}} s\right) / \frac{b}{K_{i I_{f}}} s^{2}
$$

where

$$
b=\frac{20 A_{t c i} \cdot L_{f}}{V_{d c}^{*}} ;
$$

where $A_{t c i}$ is the amplitude of the triangular carrier.

In the case of the PI regulation of the AC output current $I_{f}$, and in order to reduce the dragging error between $I_{f}$ and its reference $I_{f}{ }^{*}$, the passing-band of the PI regulator should be inferior to the cutting frequency $f_{c}$. Practically, $\omega_{c}$ is taken $0.5 \pi \cdot f_{c}[11]$.

3.4. DC/DC converters. Figure 4 exhibits the topology of $\mathrm{DC} / \mathrm{DC}$ converters. The $\mathrm{FC} \mathrm{DC} / \mathrm{DC}$ converter is unidirectional and operates in boost mode, whereas that of the battery is bidirectional and operates in boost and buck modes [9]. The power circuits in both operating modes are based on the average model allowing controlling the input voltage $V_{i}$ and the output current $I_{o}$ using regulated duty cycles $\alpha_{\text {boost }}^{*}, \alpha_{\text {buck }}^{*}$ and the efficiencies $\eta_{\text {boost }}, \eta_{\text {buck }}$ obtained from a 2-D look-up table which data is provided by the manufacturer BRUSA [12]

$$
\begin{gathered}
V_{i}^{*}=\left(1-\alpha_{\text {boost }}^{*}\right) \cdot V_{o} ; \\
I_{o}^{*}=\eta_{\text {boost }}\left(1-\alpha_{\text {boost }}^{*}\right) \cdot I_{i} ;
\end{gathered}
$$

where $V_{i}, I_{i}$ are the voltage and current at the low voltage side; $V_{o}, I_{o}$ are the voltage and current at the high voltage side.
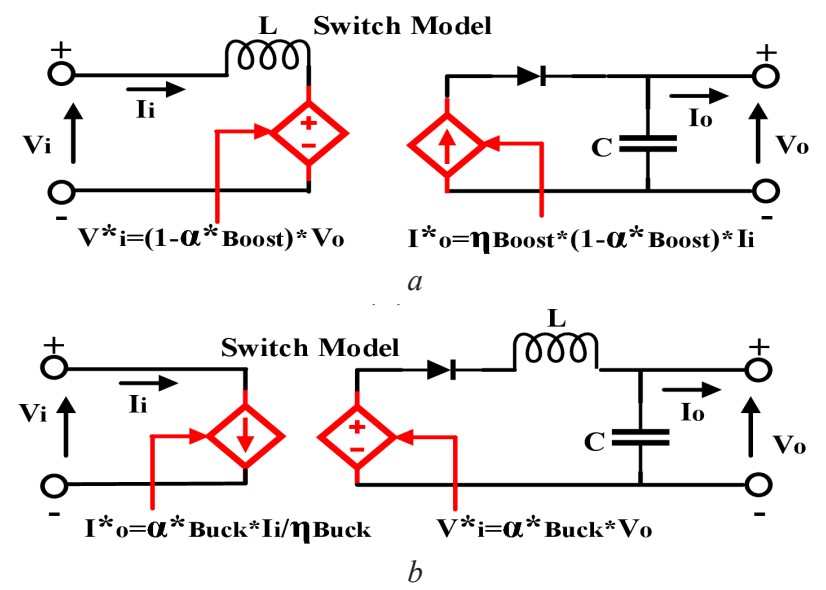

Fig. 4. DC/DC power circuit:

$a$-Boost mode; $b$ - Buck mode

Figure 5 summarizes the principle of the control circuit with voltage and current regulators of FC and battery in boost mode (Fig. 5,a,b) and battery in buck mode (Fig. 5,c). One can deduce that $\alpha^{*}{ }_{\text {boost }}$ is regulated starting from $V_{d c}^{*}$ while $\alpha^{*}$ buck can be regulated from $V^{*}{ }^{\text {ibatt. }}$
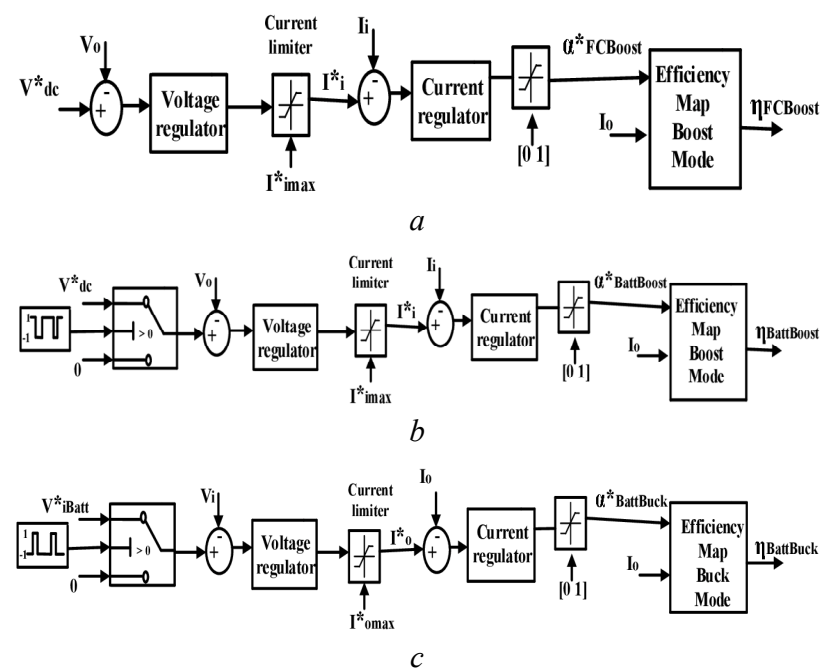

Fig. 5. DC/DC control circuit:

$a$ - fuel-cell; $b$ - Battery in Boost mode;

$c$ - Battery in Buck mode

Dimensioning of voltage and current regulators. The inductor $L$ voltage and capacitor $C$ current can be expressed as:

$$
\begin{gathered}
L \frac{d I_{i}}{d t}=V_{i}-\left(1-\alpha_{\text {boost }}^{*}\right) \cdot V_{o} \\
C \frac{d V_{o}}{d t}=\eta_{\text {boost }}\left(1-\alpha_{\text {boost }}^{*}\right) \cdot I_{i}-I_{o} .
\end{gathered}
$$


This gives the inductor current and capacitor voltage in Laplace domain as:

$$
\begin{gathered}
I_{i}(s)=\frac{V_{i}-\left(1-\alpha_{\text {boost }}^{*}\right) \cdot V_{o}}{L \cdot s} ; \\
V_{o}(s)=\frac{\eta_{\text {boost }}\left(1-\alpha_{\text {boost }}^{*}\right) \cdot I_{i}-I_{o}}{C \cdot s} ; \\
\Rightarrow V_{o}(s)=\frac{\eta_{\text {boost }}\left(\frac{V_{i}^{*}}{V_{0}}\right) \cdot I_{i}-I_{o}}{C \cdot s} .
\end{gathered}
$$

Then, the open loop transfer functions are given by:

$$
\begin{gathered}
\operatorname{OLTF}_{I}(s)=\frac{K_{P I} s+K_{I I}}{s} \cdot \frac{1}{L \cdot s} \\
\operatorname{OLTF}_{V}(s)=\frac{K_{P V} s+K_{I V}}{s} \cdot \frac{1}{C \cdot s}
\end{gathered}
$$

where the proportional gains $K_{P I}, K_{P V}$ and integral gains $K_{I I}, K_{I V}$ are determined knowing the regulator response times as [13]:

$$
\begin{gathered}
K_{P I}=2 \zeta \omega_{N I} L, K_{I I}=\omega_{N I}^{2} L \\
K_{P V}=2 \zeta \omega_{N V} C, K_{I V}=\omega_{N V}^{2} C ;
\end{gathered}
$$

where

$$
\begin{aligned}
\zeta \omega_{N I}= & \frac{-\ln \left(0.05 \sqrt{1-\zeta^{2}}\right)}{T_{R I}} ; \\
\zeta \omega_{N V}= & \frac{-\ln \left(0.05 \sqrt{1-\zeta^{2}}\right)}{T_{R V}},
\end{aligned}
$$

where $\omega_{N I}, \omega_{N V}$ are the current and voltage controller bandwidth respectively; $\zeta$ is the damping coefficient; $T_{R I}, T_{R V}$ are the current and voltage controller response times respectively. $T_{R I}$ is chosen to be one tenth of $T_{R V}$.

Similar to the model of the DC/DC boost converter, the DC/DC buck converter is shown in Fig. 4,b

$$
\begin{aligned}
& V_{o}=\alpha_{\text {buck }}^{*} \cdot V_{i}^{*} ; \\
& I_{o}^{*}=\frac{I_{i} \cdot \eta_{\text {buck }}}{\alpha_{\text {buck }}^{*}} .
\end{aligned}
$$

From the average model, the inductor $L$ current and capacitor $C$ voltage can be expressed in Laplace domain as:

$$
\begin{gathered}
I_{o}(s)=\frac{\alpha_{b u c k}^{*} V_{i}^{*}-V_{o}}{L \cdot s} \\
V_{o}(s)=\frac{I_{o}-\eta_{b u c k}\left(\frac{V_{i}}{V_{o}}\right) \cdot I_{i}}{C \cdot s} .
\end{gathered}
$$

Similar to the DC/DC boost converter control. The PI controllers gains of the buck converter control circuit are also determined using (15)-(20).

4. Study of the energy efficiency. In this section, the study aims to extract the relative power losses $X$ and the efficiency $\eta$ depending on the load factor $K_{L}$ and the load power factor $P_{F}[6,7]$. Since the power losses are mainly caused by the dispersed power in the wires resistances in the source, then in the following equations development only the source resistance $R_{s}$ will be considered.

The load factor is defined as the ratio between the short-circuit power $P_{0}$ and the load power $P_{l}$ :

$$
K_{L}=P_{0} / P_{l}
$$

where $P_{0}$ is the maximum power that can be provided to the disturbing load without reaction of the protecting equipment (fuses and circuit-breakers). Its expression is given by:

$$
P_{0}=\frac{1}{T} \int_{0}^{T} e_{S}^{T}(t) R_{S}^{-1} e_{S}(t) d t
$$

where $e_{s}$ is the vector of the instantaneous values of the source voltage:

$$
e_{S}(t)=\left[\begin{array}{c}
e_{s a}(t) \\
e_{s b}(t) \\
e_{s c}(t)
\end{array}\right]
$$

where $R_{s}$ is the matrix of resistance losses in the cables of the power system:

$$
R_{s}=\left[\begin{array}{ccc}
R_{s} & 0 & 0 \\
0 & R_{s} & 0 \\
0 & 0 & R_{s}
\end{array}\right]
$$

where $P_{l}$ is the load power formulated by:

$$
P_{l}=\frac{1}{T} \int_{0}^{T} V_{s}^{T}(t) I_{l}(t) d t
$$

where $V_{s}, I_{l}$ are the respective vectors of instantaneous values of common coupling point voltage and load current:

$$
V_{s}(t)=\left[\begin{array}{c}
V_{s a}(t) \\
V_{s b}(t) \\
V_{s c}(t)
\end{array}\right], \quad I_{l}(t)=\left[\begin{array}{c}
I_{l a}(t) \\
I_{l b}(t) \\
I_{l c}(t)
\end{array}\right]
$$

where $P_{F}$ is conventionally defined as the ratio between $P_{l}$ and the apparent power $S$ given by [6]:

$$
S=\sqrt{\frac{1}{T} \int_{0}^{T} V_{S}^{T}(t) R_{S}^{-1} V_{S}(t) d t \int_{0}^{T} I_{S}^{T}(t) R_{S} I_{S}(t) d t} ;
$$

where $I_{S}$ is the vector of instantaneous values of the source current:

$$
I_{s}(t)=\left[\begin{array}{c}
I_{s a}(t) \\
I_{s b}(t) \\
I_{s c}(t)
\end{array}\right] .
$$

The power losses $\Delta P$ are the difference between the source power $P_{s}$ given by:

$$
P_{S}=\frac{1}{T} \int_{0}^{T} e_{S}(t) I_{S}(t) d t
$$

and $P_{l}$ :

$$
\Delta P=P_{S}-P_{l}
$$

on the other hand $\Delta P$ can be expressed by:

$$
\Delta P=\frac{1}{T} \int_{0}^{T} I_{s}^{T}(t) R_{s} I_{s}(t) d t \Rightarrow \frac{S^{2}}{\frac{1}{T} \int_{0}^{T} V_{s}^{T}(t) R_{s}^{-1} V_{s}(t) d t}
$$


The term $1 / T \int_{0}^{T} V_{S}^{T}(t) R_{S}^{-1} V_{S}(t) d t$ corresponds to the useful power at the common coupling point $P_{u}$ :

$$
\begin{aligned}
& P_{u}=\frac{1}{T} \int_{0}^{T} V_{s}^{T}(t) R_{s}^{-1} V_{s}(t) d t= \\
& =P_{u}=\frac{1}{T} \int_{0}^{T}\left[e_{S}(t)-R_{S} I_{S}(t)\right] R_{S}^{-1}\left[e_{S}(t)-R_{S} I_{S}(t)\right] d t= \\
& =\frac{1}{T} \int_{0}^{T} e_{S}^{T}(t) R_{S}^{-1} e_{S}(t) d t-\frac{1}{T} \int_{0}^{T} I_{S}^{T}(t) R_{S} R_{S}^{-1} e_{S}(t) d t- \\
& -\frac{1}{T} \int_{0}^{T} e_{S}^{T}(t) R_{S}^{-1} R_{S} I_{S}(t) d t+\frac{1}{T} \int_{0}^{T} I_{S}^{T}(t) R_{S} R_{S}^{-1} R_{S} I_{S}(t) d t= \\
& =\frac{1}{T} \int_{0}^{T} e_{S}^{T}(t) R_{S}^{-1} e_{S}(t) d t-\frac{1}{T} \int_{0}^{T} I_{S}^{T}(t) e_{S}(t) d t- \\
& -\frac{1}{T} \int_{0}^{T} e_{S}^{T}(t) I_{S}(t) d t+\frac{1}{T} \int_{0}^{T} I_{S}^{T}(t) R_{S} I_{S}(t) d t= \\
& =P_{0}-P_{s}-P_{s}+\Delta P=P_{0}-P_{s}-P_{s}+P_{s}-P_{l} \text {; } \\
& \Rightarrow P_{u}=P_{0}-P_{s}-P_{l} \text {. }
\end{aligned}
$$

The efficiency $\eta$ is the ratio between the load power and the source power:

$$
\eta=\frac{P_{l}}{P_{s}}=\frac{P_{l}}{P_{l}+\Delta P}=\frac{1}{1+\frac{\Delta P}{P_{l}}} ;
$$

From $P_{F}=P_{l} / S$, one can conclude that:

$$
\begin{gathered}
\Delta P=\frac{S^{2}}{P_{u}}=\frac{P_{l}^{2}}{P_{F}^{2}+P_{u}} ; \\
\eta=\frac{1}{1+\frac{P_{l}}{P_{F}^{2}\left(P_{0}-P_{s}-P_{l}\right)}} ; \\
\Rightarrow \eta P_{F}^{2} P_{0}-\eta P_{F}^{2} P_{s}-\eta P_{F}^{2} P_{l}+\eta P_{l}- \\
-P_{F}^{2} P_{0}+P_{F}^{2} P_{s}+P_{F}^{2} P_{l}=0 ; \\
\Rightarrow \eta P_{F}^{2} \frac{P_{0}}{P_{l}}-\eta P_{F}^{2} \frac{P_{s}}{P_{l}}-\eta P_{F}^{2}+\eta- \\
-P_{F}^{2} \frac{P_{0}}{P_{l}}+P_{F}^{2} \frac{P_{s}}{P_{l}}+P_{F}^{2}=0 ; \\
\Rightarrow \eta^{2}\left(1+\left(P_{F}^{2}\left(K_{L}-1\right)\right)\right)-P_{F}^{2} K_{L} \eta+P_{F}^{2}=0 .
\end{gathered}
$$

\begin{tabular}{|c|c|}
\hline Parameter & Value \\
\hline$P_{f c \text { nom }}, P_{b a t \max }$ & $24 \mathrm{~kW}, \quad 21 \mathrm{~kW}$ \\
\hline$P_{\text {fclow }}, P_{\text {fchigh }}$ & $1.6452 \mathrm{~kW}, \quad 13.348 \mathrm{~kW}$ \\
\hline$P_{\text {fcidle, }}$, initial SOC & $316.2 \mathrm{~W}, \quad 80.1 \%$ \\
\hline AC supply voltage, $f$ & $V_{s l-\operatorname{lmax}}=400 \mathrm{~V}, f=50 \mathrm{~Hz}$ \\
\hline Maximum source current & $I_{s \max }=60.01 \mathrm{~A}$ \\
\hline Supply impedance & $R_{s}=0.5414 \Omega, \quad L_{s}=1.7 \mathrm{mH}$ \\
\hline Rectifier load & $R_{l}=8.4 \Omega, \quad L_{l}=50 \mathrm{mH}$ \\
\hline Output filter impedance & $R_{f}=2.063 \Omega, L_{f}=1 \mathrm{mH}, C_{f}=30 \mu \mathrm{F}$ \\
\hline Upstream impedance & $R_{u}=0.42 \Omega, \quad L_{u}=41.563 \mathrm{mH}$ \\
\hline DC-bus & $\begin{array}{c}V_{d c \max }=1694 \mathrm{~V}, \quad C_{d c}=617.18 \mu \mathrm{F}, \\
R_{d c}=60 \Omega, \quad L_{d c}=0.5 \mathrm{mH}\end{array}$ \\
\hline PI voltage & $f_{c V d c}=20 \mathrm{~Hz}, \quad \phi_{c V d c}=89.9^{\circ}$ \\
\hline PI current & $f_{c l f}=10 \mathrm{kHz}, \quad \phi_{c l f}=89.9^{\circ}$ \\
\hline
\end{tabular}

The determinant of (42) is given by:

$$
\begin{aligned}
\Delta & =\left(K_{L}^{2}-4 K_{L}+4\right) P_{F}^{4}-4 P_{F}^{2}>0 \\
& \Delta>0 \Rightarrow \frac{K_{L}^{2}}{4}-K_{L}+1-\frac{2}{P_{F}^{2}}>0 \\
& \Rightarrow K_{L}>2+\frac{2}{P_{F}}
\end{aligned}
$$

$$
\Rightarrow \eta=\frac{P_{F} K_{L}+\sqrt{\left(K_{L}-2\right)^{2} P_{F}^{2}-4}}{2\left(\frac{1}{P_{F}}+P_{F}\left(K_{L}-1\right)\right)} .
$$

On the other hand and using the relative power losses $X\left(X=\Delta P / P_{l}\right)$ in the efficiency formula:

$$
\eta=\frac{1}{1+X} \Rightarrow X=\frac{1}{\eta}-1
$$

5. Simulation results discussion. In this section simulation works about the previous study are presented. They were carried out using MATLAB/Simulink software and considering the parameters reported in Table 1.

Figure 6 present the imposed values of the state-ofcharge SOC (Fig. 6,a) and the regulated duty cycles $\alpha^{*}{ }_{F C B o o s t}$, $\alpha_{\text {BattBoost }}^{*}$ and $\alpha_{\text {BattBuck }}^{*}$ (Fig. 6,b).
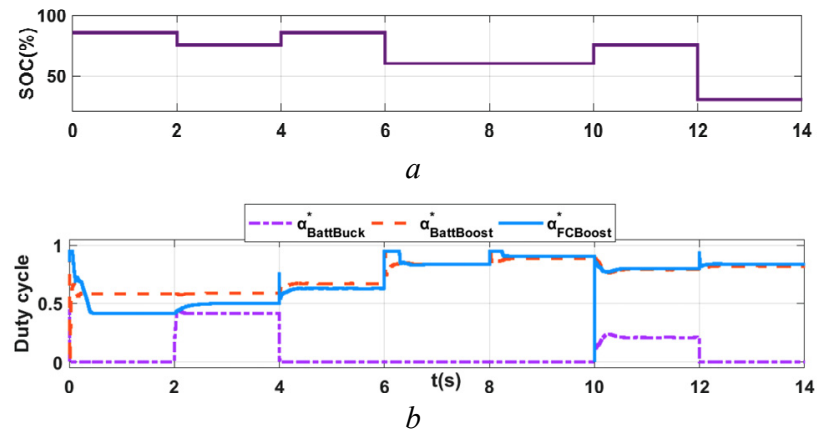

Fig. 6. $a$-the imposed state-of-charge (SOC); $b$ - regulated duty cycles of DC/DC FC and battery converters

The imposed SOCs were chosen to meet the energy management algorithm cases [9]; their values vary between $35 \%$ to $85 \%$. Accordingly, the regulated duty cycles of the boost mode of the DC/DC converters vary between 0.41 and 0.9 for the FC converter and between 0.58 and 0.88 for the battery converter. In the case of the battery buck mode, the duty cycle varies between 0 and 0.4 . Since the battery begins alone to feed the DC bus until the 
FC enters in operation, $\alpha_{\text {BattBoost }}$ is superior to $\alpha^{*_{F C B o o s t}}$. Then, the two duty cycles become superimposed in their evolution once the FC is operational. For the case of $\alpha_{\text {BattBuck }}$, one can observe that it is null all the time except when the battery is in the charging mode (case of $P_{\text {fcidle }}<P_{\text {dem }}<P_{\text {fclow }}$ and SOC $<80 \%$, and $P_{\text {dem }}>P_{\text {fclow }}$ and SOC $<80 \%$ [9]). The value of $\alpha^{*}{ }_{\text {BattBuck }}$ is low because of the low percentage of the battery discharge.

Now, which concerns the different considered powers $\left(P_{\text {dem }}, P_{f c}, P_{b a t t}\right)$, the results are displayed in Fig. 7. The results are presented into two shutters. The first one deals with the obtained powers before regulating the duty cycles (Fig. 7,a) while the second one shows the powers after activating the duty cycle regulation loops (Fig. 7,b). It is obvious that there are some differences, especially for $P_{f c}$ and $P_{b a t t}$ from their respective reference values obtained from the energy management algorithm [9], before regulating the DC/DC converters duty cycles (Fig. 7,a). However, the differences disappear when the duty cycles are regulated (Fig. 7,b).
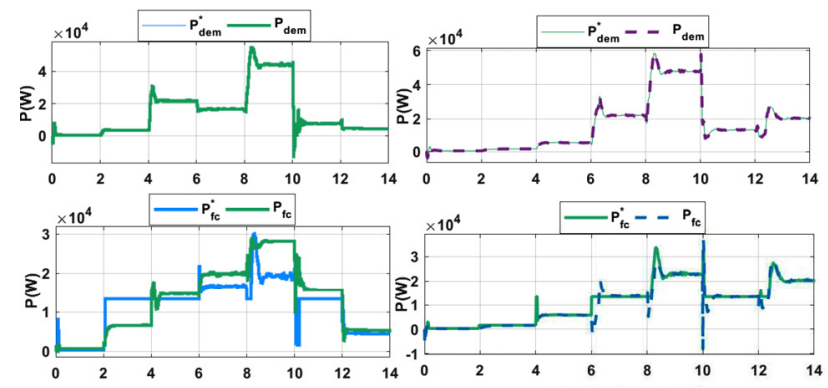

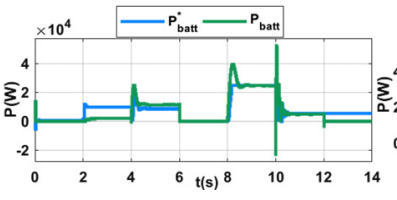

$a$

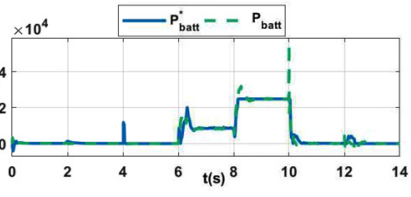

$b$
Fig. 7. Reference and measured powers of the demand, the FC and the battery.

$a$ - before duty cycles regulation; $b$-after duty cycles regulation

Figure 8 depicts the input/output currents and voltages, with their respective references, of the DC/DC converters. Figure 8,a shows the FC input reference current $I_{i f c}^{*}$, the FC input measured $I_{i f c}$ and the measured output current $I_{o f c}$. Notably, $I_{i f c}$ is perfectly following its reference $I_{i f c}^{*}$. Which concerns $I_{o f c}$, it is all time inferior to $I_{i f c}$ because of the boost mode of the FC DC/DC converter. The same observation can be pointed-out for Fig. $8, b$ concerning the battery currents in the boost mode of its converter. Figure 8,c shows the battery currents when its converter is in the buck mode where low values are noted compared to the boost mode values. Figure 8, $d$ presents the demand current measured $I_{d e m}$ in the DC bus which is the sum of $I_{o f c}$ and $I_{\text {obatt }}$. Similar remarks can be given for the different input/output voltages (Fig. 8,e to Fig. $8, g$ ), only this time, output voltages are superior to input voltages in the boost mode (Fig. 8,e and Fig. 8,f) and vice-versa in the buck mode (Fig. 8,g). Finally, Fig. $8, h$ portrays the demand voltage superimposed to its reference. Different reference voltage levels were imposed in order to meet the energy management algorithm cases [9].
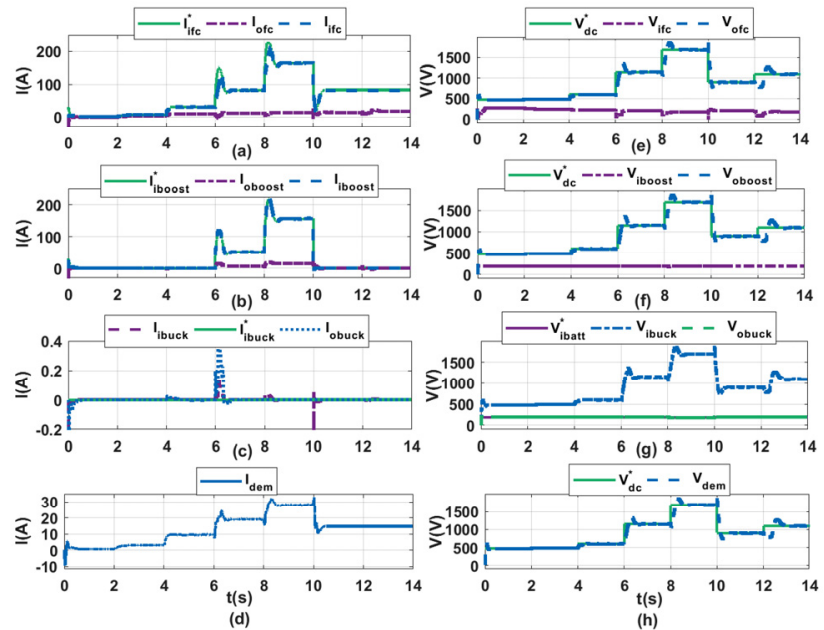

Fig. 8. Input and output measured and reference currents and voltages of DC/DC converters:

$a-\mathrm{DC} / \mathrm{DC}$ FC boost converter currents;

$b-\mathrm{DC} / \mathrm{DC}$ battery boost converter currents;

$c-\mathrm{DC} / \mathrm{DC}$ battery buck converter currents; $d$ - the demand current;

$e-\mathrm{DC} / \mathrm{DC}$ FC boost converter voltages;

$f-\mathrm{DC} / \mathrm{DC}$ battery boost converter voltages;

$g-\mathrm{DC} / \mathrm{DC}$ battery buck converter voltages; $h$ - the demand voltage

Figure 9 concerns the filtering instantaneous results in the AC feeder of Fig. 1 after inserting the SAPF. The displayed curves are related to the 3-phase current absorbed by nonlinear load (Fig. 9,a), the AC source 3-phase current (Fig. 9,b) and the 3-phase point of common coupling (PCC) voltage (Fig. 9,c). It is noted that the load current is hardly distorted while the source current and voltage are near-sinusoidal waves.

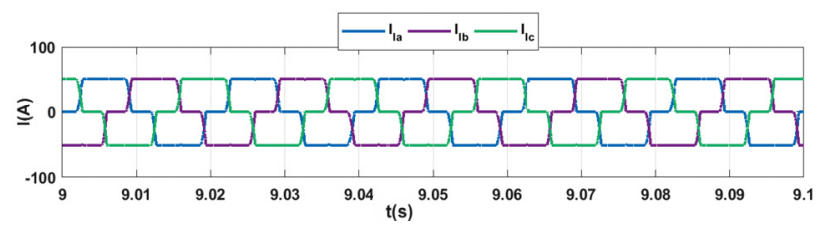

$a$

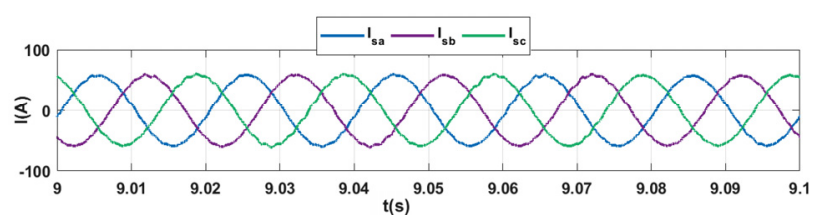

b

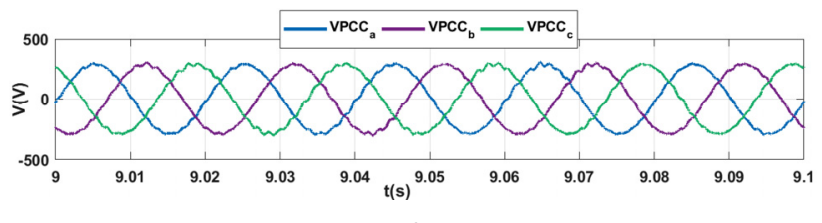

c

Fig. 9. Results after inserting the SAPF: $a$ - load current; $b$ - source current; $c$ - PCC voltage

The harmonic spectrums shown in Fig. 10 provide frequency analysis before and after inserting the 
regulation loops of the DC/DC converters duty cycles. The total harmonic distortion (THD) of the load current is around $25 \%$ (Fig. 10,a), the THD of the source current before regulating the duty cycles is $2.38 \%$ (Fig. 10,b) and the source voltage THD is $3.03 \%$ (Fig. 10,c). After inserting the duty cycles regulation loops the source current and voltage THDs \% decrease respectively to $2.08 \%$ (Fig. 10,d) and $2.92 \%$ (Fig. 10,e) which means an improvement in the filtering quality when activating the regulation of the $\mathrm{DC} / \mathrm{DC}$ converters duty cycles.
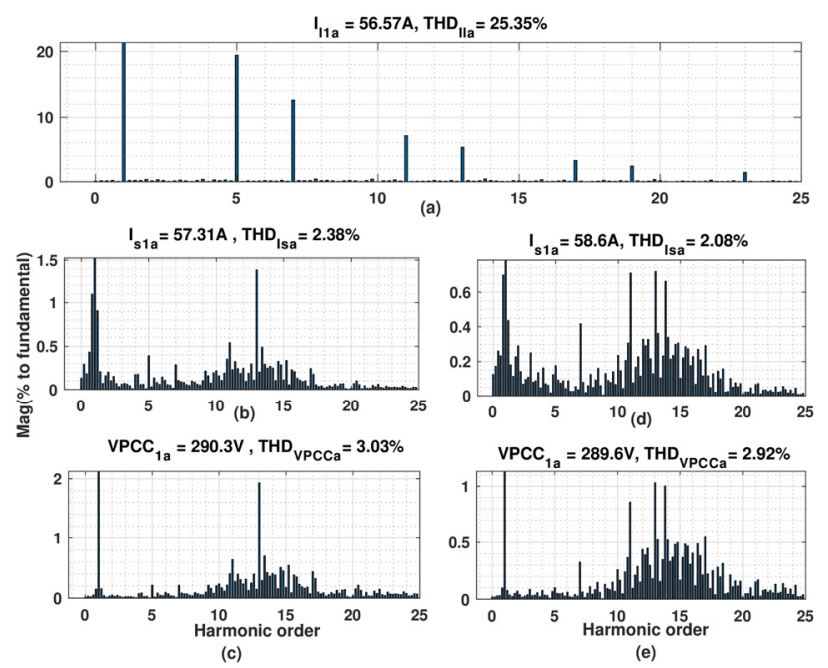

Fig. 10. Harmonic spectrum of: $a$ - load current. Before duty cycles regulation:

$b$ - source current; $\mathrm{c}$ - PCC voltage. After duty cycles regulation:

$d$ - source current; $e$ - PCC voltage

In Fig. 11 the results concerning the SAPF are presented.

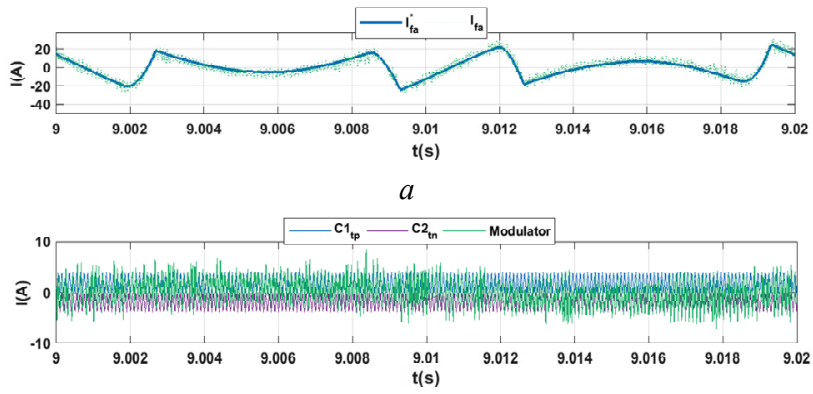

$$
b
$$

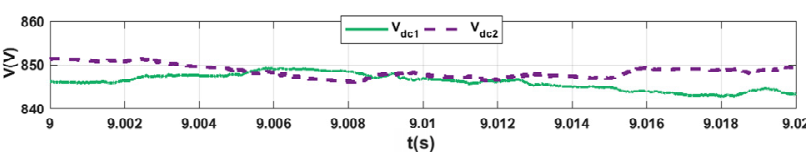

c

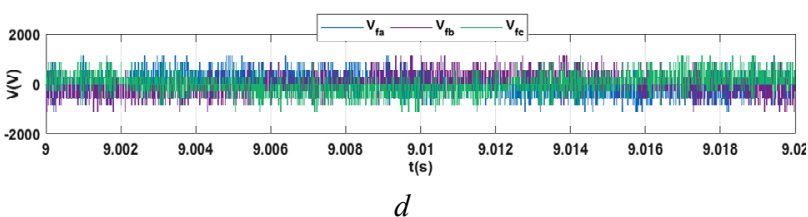

Fig. 11. A zoom in for $V_{d c}^{*}=1694 \mathrm{~V}$ : $a$ - the APF current $I_{f}$ with its reference;

$b$ - modulator with carriers;

$c$ - DC-bus voltage levels;

$d$ - output filter voltage
Figure 11, $a$ shows the current of the SAPF with perfect agreement with its reference. Figure $11, b$ illustrates the modulating signal $\left(I_{f}^{*}-I_{f}\right)$ varying inside its carrier signal which means a satisfying operation of the considered pulse-width modulation (PWM) strategy. In Fig. 11,c the regulated two voltages of the DC bus $V_{d c 1}$ and $V_{d c 2}$ are presented. One can observe that they evolve in an opposite manner around $V^{*}{ }_{d c} / 2$ (the case of $V^{*}{ }_{d c}=1694 \mathrm{~V}$ is considered). Finally, the output voltages of the SAPF are shown in Fig. 11, $d$ where 3-levels can be read: $\approx 2 V^{*}{ }_{d c} / 3(1126 \mathrm{~V}), \approx V^{*}{ }_{d c} / 2(845 \mathrm{~V})$, and $\approx V^{*}{ }_{d c} / 3$ $(565 \mathrm{~V})$ which demonstrates a good behavior of the 3-level SAPF.

Figure 12 concerns the power quality characterization using the instantaneous THDs of the source current and voltage (Fig. 12,a), the source current unbalance rate (CUR) (Fig. 12,b) and both power factors of the source and load (Fig. 12,c). During a transient state of $4 \mathrm{~s}$, the THDs are exceeding the standardization limits $(5 \%)$. After that, they remain below the limit. The CUR is all time low, and the source power factor is near-unity.
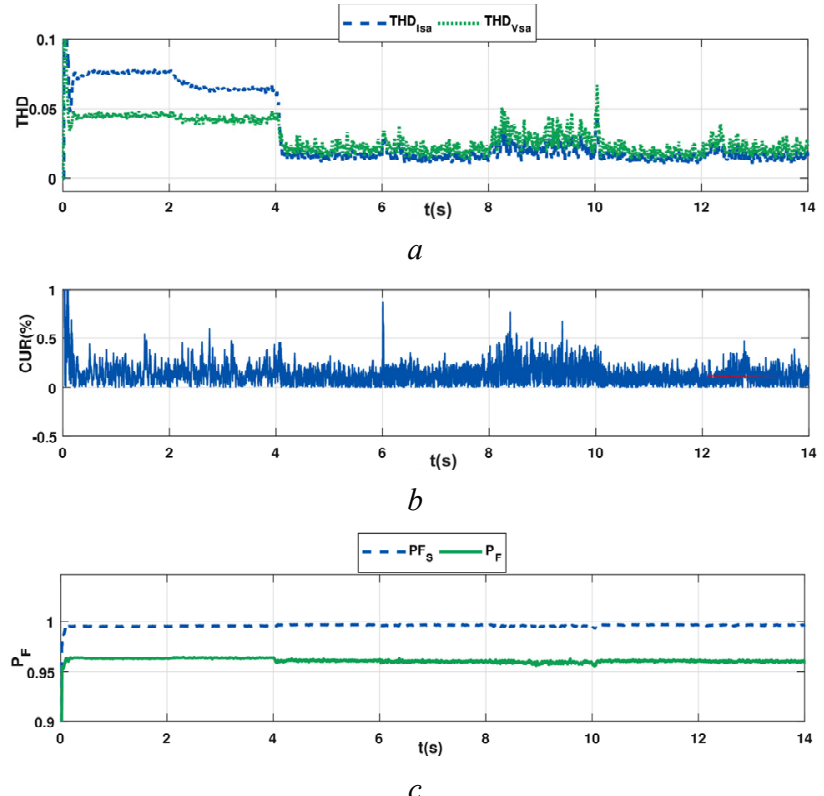

Fig. 12. Curves: $a$-total harmonic distortion THD; $b$ - current unbalance rate (CUR); $c$-power factor

Figure 13 presents the obtained result from the energy efficiency study of the system of Fig. 1.

Figure 13, $a$ depicts the short-circuit power $P_{0}$ that increases linearly from 0 and stabilizes at $293 \mathrm{~kW}$ after 0.02 s. Figure $13, b$ shows the load power $P_{l}$ which stabilizes at $23.31 \mathrm{~kW}$. Figure 13,c illustrates the ratio between $P_{0}$ and $P_{l}$ describing a decreasing curve that stabilizes at 12.36 while the power factor $P_{F}$ of Fig. 13,d is an increasing curve that trends towards 0.96 (near-unity value). In Fig. 13,e one can observe that (44) $\left(K_{L}>2+\left(2 / P_{F}\right)\right)$ is satisfied all-time. 

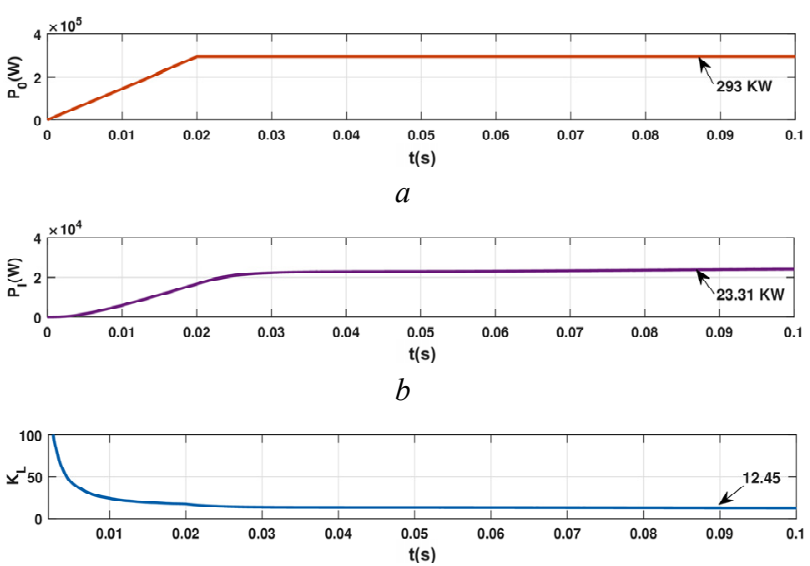

c

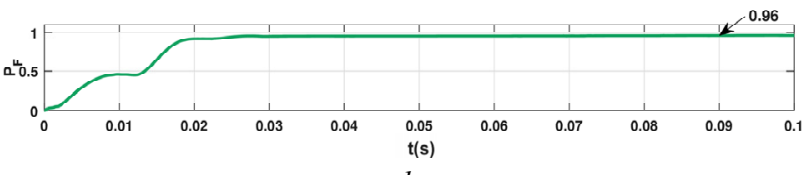

d

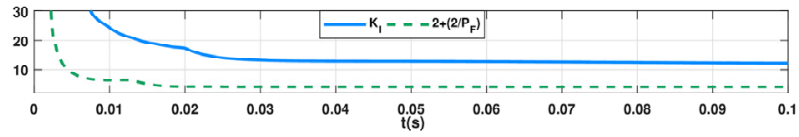

Fig. 13. The instantaneous: $a$ - short-circuit power;

$b$-load power; $c$ - load factor; $d-$ load power factor; $e-K_{L}$ and $2+\left(2 / P_{F}\right)$

Figure 14 concerns the results about the relative power losses $X$ and the efficiency $\eta$. As shown in Fig. 14, $a$ presenting $X$ vs. $P_{F}$ for different values of $K_{L}$, the relative power losses $X$ decrease when both $P_{F}$ and $K_{L}$ increase. The same observation can be pointed-out for $X$ vs. $K_{L}$ for different values of $P_{F}$ (Fig. 14,b). Now, for the efficiency $\eta$, one can observe that it increases when $P_{F}$ and $K_{L}$ increase as portrayed in Fig. 14,c ( $\eta$ vs. $P_{F}$ for different values of $\left.K_{L}\right)$ and Fig. $14, d\left(\eta\right.$ vs. $K_{L}$ for different values of $\left.P_{F}\right)$.
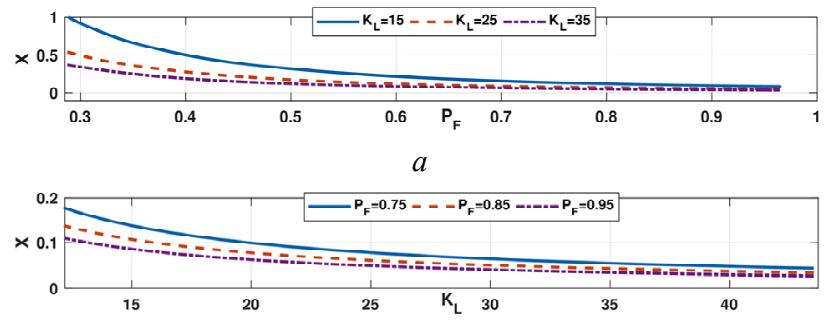

$b$

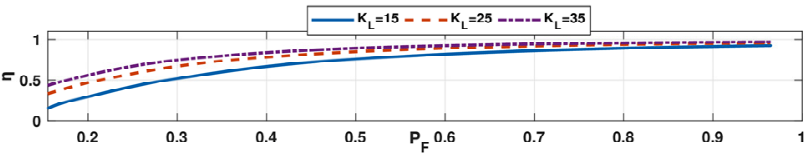

$c$

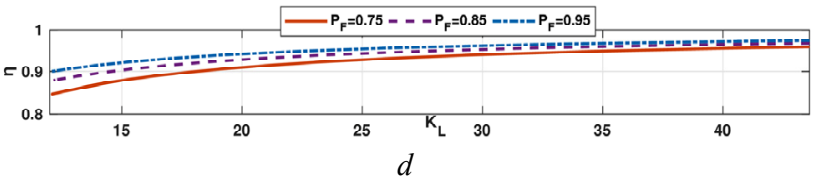

Fig. 14. Variation of: $a$ - the power losses $X$ vs. $P_{F}$ for different value of $K_{L}$;

$b$ - the power losses $X$ vs. $K_{L}$ for different value of $P_{F}$; $c$ - the efficiency $\eta$ vs. $P_{F}$ for different value of $K_{L}$; $d$ - the efficiency $\eta$ vs. $K_{L}$ for different value of $P_{F}$

\section{Conclusions.}

In this paper, the focus was on studying the energy efficiency of a system based on a 3-level shunt active filter powered by a hybrid FC/battery DC bus. The first part of the presented and discussed works concerned the duty cycles regulation of the DC/DC converters controlling the powers of the $\mathrm{FC}$, the battery and the demand together with an energy management algorithm. When comparing the obtained powers before and after regulation of the duty cycles, it was obvious that better following of these powers to their references (obtained from the energy management algorithm) is reached for a regulated duty cycle. The second part of the works concerned the energy efficiency study tacking intoaccount the short circuit power, the load power; the ratio between them noted the load factor and the load power factor. The studies were established on the relative power losses and the efficiency. The theoretical equations and simulation results demonstrate that more the load factor and the load power factor are increasing, more the power losses decrease and the efficiency increases. Future works are based on developing an optimization algorithm that improves the whole system behavior.

Conflict of interest. The authors declare that they have no conflicts of interest.

\section{REFERENCES}

1. Sumper A., Baggini A. Electrical Energy Efficiency: Technologies and Applications. John Wiley \& Sons, Ltd, 2012. 402 p. doi: https://doi.org/10.1002/9781119990048.

2. Kuznetsov V., Tryputen N., Kuznetsova Y. Evaluating the effect of electric power quality upon the efficiency of electric power consumption. 2019 IEEE 2nd Ukraine Conference on Electrical and Computer Engineering (UKRCON), 2019, pp. 556-561. doi: https://doi.org/10.1109/ukrcon.2019.8879841.

3. Toader C., Postolache P., Golovanov N., Porumb R., Mircea I., Mircea P. Power quality impact of energy-efficient electric domestic appliances. 2014 International Conference on Applied and Theoretical Electricity (ICATE), 2014, pp. 1-8. doi: https://doi.org/10.1109/icate.2014.6972627.

4. Montano J.-C., Salmeron P., Thomas J.P. Analysis of power losses for instantaneous compensation of three-phase four-wire systems. IEEE Transactions on Power Electronics, 2005, vol. 20, no. 4, pp. 901-907. doi: https://doi.org/10.1109/TPEL.2005.850956. 5. Rajalakshmi R., Rajasekaran V. Improvement of energy efficiency through power quality by the compensation of harmonics with shunt active power filter. 2011 International conference on recent advancements in electrical, electronics and control engineering, 2011, pp. 324-327. doi: https://doi.org/10.1109/ICONRAEeCE.2011.6129820.

6. Artemenko M.Y., Batrak L.M. The new formula for apparent power and power losses of three-phase four-wire system. 2017 IEEE 37th International Conference on Electronics and Nanotechnology (ELNANO), 2017, pp. 389-393. doi: https://doi.org/10.1109/ELNANO.2017.7939784.

7. Artemenko M.Y., Batrak L.M., Polishchuk S.Y., Mykhalskyi V.M., Shapoval I.A. The effect of load power factor on the efficiency of three-phase four-wire power system with shunt active filter. 2016 IEEE 36th International Conference on Electronics and Nanotechnology (ELNANO), 2016, pp. 277-282. doi: https://doi.org/10.1109/ELNANO.2016.7493067.

8. Artemenko M.Y., Batrak L.M., Domaskina N.I. Apparent power of three-phase four-wire system in sinusoidal asymmetric mode and energy effectiveness of shunt active filters. 2015 
IEEE 35th International Conference on Electronics and Nanotechnology (ELNANO), 2015, pp. 469-474. doi: https://doi.org/10.1109/ELNANO.2015.7146952.

9. Bourouis B., Djeghloud H., Benalla H. An innovative algorithm for a hybrid $\mathrm{FC} /$ battery system energy management. Electrical Engineering \& Electromechanics, 2020, no. 6, pp. 35 44. doi: https://doi.org/10.20998/2074-272x.2020.6.06.

10. Bourouis B., Djeghloud H., Benalla H. Three-Level NPC Shunt Active Filter Powered by a Hybrid Fuel-Cell/Battery DC Bus Voltage. 2021 18th International Multi-Conference on Systems, Signals \& Devices (SSD), 2021, pp. 330-339. doi: https://doi.org/10.1109/ssd52085.2021.9429308.

11. Ladoux P., Olle G. Compensateur d'harmoniques et de puissance réactive. RESELEC Publ., 2002. 45 p. (Fra). Available https://eduscol.education.fr/sti/sites/eduscol.education.fr.sti/files /ressources/techniques/3877/3877-compensateurharmoniques.pdf (accessed 12 March 2021).

12. Available https://www.brusa.biz/portfolio/bdc546/?lang=en (accessed 12 March 2020).

13. Motapon S.N. Design and simulation of a fuel cell hybrid emergency power system for a more electric aircraft: evaluation of energy management schemes. $\mathrm{PhD}$ Thesis Presented to École de Technologie Supérieure, Montreal, March 2013. Available at: https://www.proquest.com/docview/1501641145 (accessed 12 March 2021).

Received 05.07.2021

Accepted 31.08.2021

Published 26.10.2021

Billel Bourouis ${ }^{1}$, PhD Student,

Hind Djeghloud ${ }^{2}$, Lecturer,

Hocine Benalla ${ }^{1}$, Professor,

${ }^{1}$ Laboratory of Electrotechnics of Constantine (LEC),

Mentouri Brothers University, Constantine 1,

Campus Ahmed Hamani Zerzara,

Route d'Ain el Bey, Constantine, 25000, Algeria,

e-mail: billelbourouis1@outlook.com (Corresponding author), benalladz@yahoo.fr

${ }^{2}$ Laboratory of Electrical Engineering of Constantine (LGEC),

Mentouri Brothers University, Constantine 1,

Campus Ahmed Hamani Zerzara,

Route d'Ain el Bey, Constantine, 25000, Algeria.

e-mail: hinddjeghloud@yahoo.fr

How to cite this article:

Bourouis B., Djeghloud H., Benalla H. Energy efficiency of a 3-level shunt active power filter powered by a fuel cell / battery DC bus with regulated duty cycles. Electrical Engineering \& Electromechanics, 2021, no. 5, pp. 30-38. doi: https://doi.org/10.20998/2074-272X.2021.5.05. 